\title{
REVIEW
}

\section{Robert Eisen}

\section{The Peace and Violence of Judaism: From the Bible to Modern Zionism}

(New York: Oxford University Press, 2011), hardcover, $x+265$ pp.

Christopher Leighton, Institute for Christian \& Jewish Studies

In his most recent book, The Peace and Violence of Judaism, Robert Eisen, Professor of Religion and Judaic Studies at George Washington University, has left the comforts of the ivory tower and taken up residence at the dangerous intersection where religion and politics converge. In prose purged of arcane academic jargon and in a format organized to provide a clear and comprehensive overview, Eisen conducts a tour into the conflicted heart of the Jewish tradition. Over the course of five chapters, the reader moves from the Bible to classical rabbinic texts to medieval Jewish philosophy and Kabbalah before entering the vexed territory of modern Zionism, where religious and secular sensibilities are frequently entangled. At every juncture, Eisen surveys the prevailing Jewish views of the non-Jew and then proceeds to trace the currents of the tradition that advance peace as well as the countervailing teachings that sanction violence.

Eisen's overview provides a welcome corrective to the reductionist indictments of Richard Harris, Richard Dawkins, Christopher Hitchens, and others who fabricate a categorical boogeyman known as "religion" and argue that it is essentially, and therefore irreparably, bellicose (p. 10, 17). This volume dispels such simplisms without minimizing the difficulties of disarming the toxic legacies of our religious communities. As Eisen unflinchingly acknowledges, there are alarming obstacles within the Jewish tradition to confront (which of course are mirrored and exaggerated within Christianity and Islam). He graphically illustrates the point in his analysis of traditional kabbalistic claims that Jewish souls emanate from the realm of sefirot, while non-Jewish souls stem from a domain of impurity and evil and do not reflect "the image of God" (p. 132). This metaphysical assertion represents a revealed truth and therefore is not subject to rational critique. To offset disturbing claims about "Jewish souls" over and against their non-Jewish inferiors, Eisen notes the historical circumstances of political, economic, and social oppression of the Jewish community to account for (although certainly not to excuse!) the demonization of Gentiles. Furthermore, he profiles adherents of Kabbalah who espouse far more positive assessments of non-Jews and recapitulate rabbinic teachings about so-called righteous Gentiles who will receive their divine rewards in the world to come.

This pattern of juxtaposing the dangerous dimensions of the Jewish tradition alongside teachings that blunt polemical excesses and advocate more irenic positions is utilized in each chapter, and the result is a study that brings the reader into an insoluble ambiguity within Judaism. The tradition contains texts that, for example, demean Gentiles as latter-day manifestations of the biblical foe Amalek and justify violence. At the same time, the tradition is loaded with counter-examples of teachings that deepen understandings of a common humanity and promote peace. There were occasions when I longed for a fuller and more thorough exposition. While the footnotes provide indispensable information about sources, many of the most challenging philosophical and theological tensions are relegated to fine print. The long chapter on Modern Zionism was the 
welcome exception. Here Eisen draws on the statements of a wide variety of religious, political, and intellectual leaders to probe the complexities and entanglements of secular and religious thought. He demonstrates that the lines between religious and political domains are porous, and he brings into sharp focus tensions that in large measure shape the sensibilities of Israeli society. Throughout this volume, Eisen strives for balance. Only at the end, in his epilogue, does he disclose his own political-religious views. Relying on a consequentialist ethic that emphasizes practical outcomes and that he finds in both Western philosophical and traditional Jewish thought, he argues that Jewish survival is best served by a more diplomatic approach to the Israeli-Palestinian conflict. Although he is no pacifist, he worries about Israel's long-term viability if a right-wing perspective, which he thinks overstates Israel's ability to successfully deploy military strength, prevails.

Eisen largely focuses on those facets of the Jewish tradition that enshrine "the other" as a threatening outsider. He deals less often with the fact that the bloodiest of battles are more often than not family affairs, though he rightly discusses the assassination of Prime Minister Yitzhak Rabin by a radical Jew (p. 158). It is proximity rather than distance that often proves lethal. This dynamic is especially pertinent with respect to the future of Zionism and the State of Israel. To be sure, the potential for cataclysmic violence between Israelis and Palestinians looms large, but this prospect should not deflect our attention from the polarization of religious and secular sectors of Israeli society. The differences between right-wing and left-wing Israelis may be held in check by external enemies, but what will become of Israel's civil order if a negotiated peace calls for the relocation of hundreds of thousands of settlers? These topics are raised, and I would have welcomed even greater attention to the dangers that well up from within a community and that threaten societies with internecine strife. The most destabilizing outbursts of violence may break through these fissures within Israel and the larger Jewish community.

Eisen's work will hopefully provoke searching conversations within the Jewish community by bringing to light ambiguities and tensions that many would prefer to ignore or deny. He offers an important model to Christians and Muslims who must confront similar challenges and far more deadly legacies. Were Jews, Christians, and Muslims willing to attend to the double-edged character of their respective traditions and to highlight those particular strategies of interpretation that defang their venomous excesses, they just might discover that they have something of vital importance to learn from one another and to offer the world. 